\title{
Arsenic in Shallow Aquifers Linked to the Electrical Ground Conductivity: the Mekong Delta Source Example
}

\author{
Van Phan T.H $H^{1,2}$, Timothée Bonnet ${ }^{1}$, Stéphane Garambois ${ }^{1}$, Delphine Tisserand ${ }^{1}$, Fabrizio Bardelli ${ }^{1}$, \\ Rizlan Bernier-Latmani ${ }^{3}$, Laurent Charlet $^{1}$ \\ ${ }^{1}$ Université Grenoble Alpes - Institut des Sciences de la Terre (ISTerre), F-38041 Grenoble, France \\ ${ }^{2}$ Ho Chi Minh City University of Technology (HCMUT) - Vietnam National University - Ho Chi Minh City \\ (VNU-HCM), 268 Ly Thuong Kiet, District 10, Ho Chi Minh City, Vietnam \\ ${ }^{3}$ Ecole Polytechnique Fédérale de Lausanne (EPFL) - Environmental Microbiology Laboratory (EML) \\ EPFL-ENAC-IIE-EML, Station 6, CH-1015 Lausanne, Switzerland \\ Email: phanhaivan@gmail.com
}

\begin{abstract}
Heavy arsenic (As) contamination of groundwater is investigated in the An Giang province of Vietnam to better understand the interplay between surface sedimentology and anoxic aquifer. In particular, the present study aims to compare As concentrations measured in groundwater pumped from 40 shallow wells ( $<40 \mathrm{~m}$ in depth) along the lower Mekong stream with surface variations of electrical conductivity measured using an electromagnetic geophysical device (EM 31). Based on the analytical results for groundwater, core sediments and geophysical data, we show the permeability and clay content of surface soil derived through EM conductivity measurement to have a positive and significant correlation $\left(\mathrm{R}^{2}=0.83, \mathrm{n}=27\right)$ with the distribution of As concentration in shallow aquifers. This indicates that the presence of soil and subsoil claypan can enhance the reducing conditions in the aquifer. The results also suggest the important role of $\mathrm{HCO}_{3}^{-}, \mathrm{Fe} / \mathrm{Mn}$ (oxyhydr)oxides and clay minerals in mobilizing As groundwater leading to a major health threat to local people of this province.
\end{abstract}

Keywords: Mekong Delta, electrical ground conductivity, arsenic, shallow aquifer, iron (oxyhydr)Oxides.

\section{Introduction}

Arsenic (As) contamination in groundwater has been a serious concern worldwide in recent years. Chronic exposure can adversely affect human dermal, cardiovascular, gastrointestinal, hepatic, neurological, pulmonary, renal, respiratory and reproductive systems (Mandal \& Suzuki, 2002; WHO, 2004). Currently, As is recognized as a carcinogen not only causing skin cancer but also potential generating to other internal cancers including liver, lung, bladder and kidney cancers (Smith et al., 1992; Smith et al., 2009). Consequently, the present standard for drinking water supply places the upper limit of As concentration at $10 \mu \mathrm{g} / \mathrm{L}$ in many countries (Smedley \& Kinniburgh, 2002). Some developing countries, like Bangladesh for example, have maintained the former $50 \mu \mathrm{g} / \mathrm{L}$ standard maximum level (Ng et al., 2003). In Vietnam, high As concentrations have been reported both in the Northern part within the Red River delta and in the Southern part within the Mekong River delta, where a large population uses As-rich groundwater for drinking and/or irrigation purposes (Agusa et al., 2007; Berg et al., 2007; Buschmann et al., 2008; Erban et al., 2013; Merola et al., 2015; Polizzotto et al., 2005; Stanger et al., 2005; Stuckey et al., 2015; Winkel et al., 2010). The arsenic content has been high in $64 \%$ of tested people living in the Red River Delta area. Hair and urine samples had more than $1 \mu \mathrm{g} / \mathrm{g}$ in this part of the population, a level linked with the appearance of arsenic intoxication diseases (Agusa et al., 2014). Approximately 16 million people in Vietnam and Cambodia living in the Mekong Delta River area are therefore at risk due to high As concentration levels in their drinking water. Using the nail to water As ratio, Merola et al. (2015) suggested bioaccumulation of As should occur for all populations who consume groundwater (Merola et al., 2015). This is particularly true for residents of An Phu and 
Phu Tan districts, who consumed As-contaminated groundwater for a decade, and are found to have an increased As concentration in the hair (Hanh et al., 2011). Arsenic of Southeast Asian delta aquifers derives from Himalayan sediment deposition. Once these sediments are ultimately capped with a clay layer, development of anoxic condition will be followed by a reductive release from solid phases under reducing conditions (Polizzotto et al. 2005; Stanger et al. 2005; Stuckey et al. 2015). In the Mekong River Delta, distribution of As aqueous concentration in the shallow aquifer varies widely from 1 to 1610 $\mu \mathrm{g} / \mathrm{L}$ (Erban et al., 2013; Nguyen \& Itoi, 2009) and the average As value decreases according to the increase of the distance from the well to the river increases (Merola et al., 2015). Limited predictability of As concentration in a given aquifer is due to the large spatial variability of the geology of the Mekong deltaic system. Despite underlying geological and hydrological complexities, the interaction of multiple factors controlling As has been clarified in order to better understand how the heavily As-polluted aquifer developed so as to reduce population exposure in a short term (Aziz et al., 2008; Métral et al., 2008; Nath et al., 2010). Recently, a new conceptual model for As sources and sinks in Mekong delta sediment has been proposed including a mixture of As-bearing Fe (oxyhydr)oxides, As-bearing pyrite and $\mathrm{C}$ nanotube-associated amorphous P-Ca-Mg (Wang et al., submitted). In the redox transition zone, iron (oxyhydr)oxides are reduced and As is partially leached from the amorphous P-Ca-Mg precipitate. In the deeper layer containing pyrite, As is also leached from the amorphous precipitate, but it is at least partially immobilized by natural organic matter (NOM) as thiol-As(III) bound OM. The present study is an attempt to shed some new light on the origin of this spatial variability by applying an established and simple geophysical surveying technique, frequency electromagnetic induction, and to study the correlation between deduced electrical conductivity variations to As concentration and water chemistry in Mekong Delta shallow aquifers.

Frequency inductive electromagnetic (EM) geophysical surveys have been used widely in hydrology to map infiltration of water within near-surface formations, to estimate the extent and internal structure of shallow aquifers, and to determine the extent of groundwater contamination (Aziz et al., 2008; Mcneill, 1990; Pellerin, 2002; Pettersson \& Nobes, 2003). Electrical conductivity mapping has also helped classify soil types and sometimes estimate depths of claypans (Doolittle et al. 1994; Doolittle et al. 2014). Because of its fast acquisition, ease of use, relative low cost, and a wealth of data collected at once, conductivity measurements performed using Ground Conductivity Meters devices present immense advantages compared to soil information collected from individual cores. Instrumentation has been improved to integrate global-positioning systems (GPS) to EM measurements within a data logger. Ground Conductivity Meters measure changes in the apparent electrical conductivity $(\sigma)$ of subsurface without direct contact with the sampled material. Variations of measured $\sigma$ are produced by changes in soil material electrical conductivity and increase with the presence of more mineralized water (salt content) and/or clay content in the subsoil, which themselves maintain a high "cation exchange ion" content in interlayer water. Relating inductive electromagnetic conductivity and resistivity to As concentration in groundwater has been performed in Bangladesh and India (Aziz et al., 2008; Charlet et al., 2007; Kumar et al., 2014; Métral et al., 2008; Nath et al., 2010). The advantage of electromagnetic methods is that it provides an improved spatial resolution when used in the mapping mode (Mcneill, 1990) but with limited depth information. In these studies, EM conductivity has been used to evaluate the relationship between the permeability of surface soils and the distribution of As concentration in shallow aquifers.

The present study focuses on the processes that may regulate water As concentration at shallow depths $(<40 \mathrm{~m})$ in seven exploited Holocene-Miocene aquifers. Field observations extend over a $9 \mathrm{~km}^{2}$ area in the An Phu district, An Giang province, where high As concentrations in groundwater have been reported (Erban et al., 2014; Hoang et al. 2010; Nguyen and Itoi 2009) (Fig. 1). Our study compares the spatial distribution of superficial electrical conductivity measured using an electromagnetic mapping technique (EM 31) with the As concentrations in groundwater sampled from 40 shallow wells located in open fields in this region. 


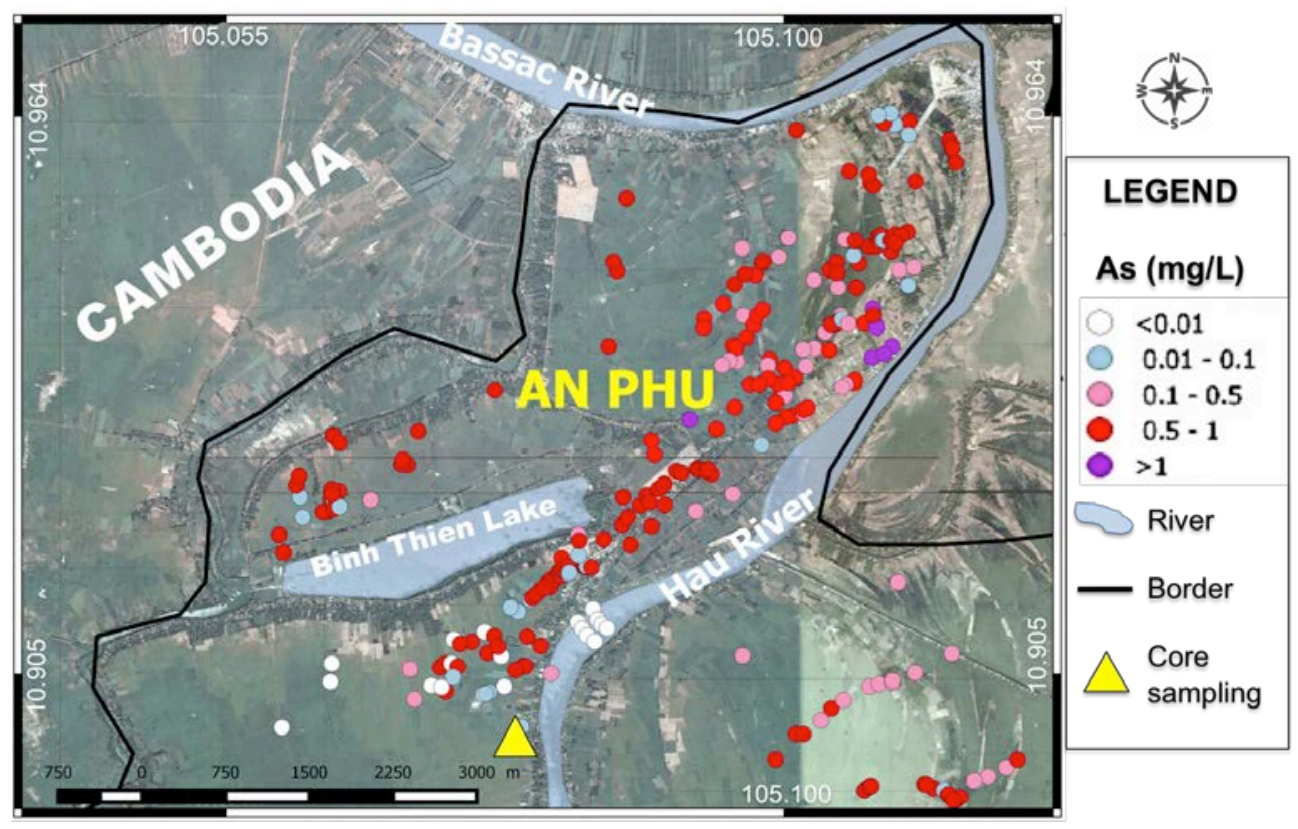

Figure 1. Distribution of arsenic in An Phu groundwater of An Giang province, the vicinity of Hau River of Mekong Delta (Erban et al., 2013).

\section{Materials and Methods}

\subsection{Geological and Hydrogeological Setting of Study Site}

The area of lower Mekong Delta is densely populated and presents appropriate conditions for agriculture. Aquifers were formed by continental sedimentary deposits and developed in a wide Quaternary plain. Most of this region has low elevation with the range of $0-4 \mathrm{~m}$ above sea level and the delta regularly suffers from flooding originating from upper Mekong Delta River and from tidewater. The Holocene sedimentary sequences are controlled by the changes in Late Pleistocene topography, sea level and sediment supply. Geologically, the area contains Holocene sediments mainly composed of fluvial deposits, up to $20 \mathrm{~m}$ thick (Nguyen \& Itoi, 2009).

\section{$2.2 \quad$ EM 31 Electromagnetic Ground Conductivity Survey}

The geophysical survey of the study area was conducted with a Geonics ${ }^{\circledR}$ EM31 instrument. This equipment consists of a transmitter coil radiating an electromagnetic field at $9.8 \mathrm{kHz}$ and a received coil located at the opposite end of $3.66 \mathrm{~m}$ long boom. This primary field induces eddy currents in the conductive ground, generating a secondary electromagnetic field that is recorded by the receiving coil. The intensity and dephasing of the secondary field increase with the conductivity of the soil, which can then be measured. This conductivity is a function of the concentration of ions dissolved in soil water as well as exchangeable ions at the solid/liquid interface and increases with clay content. The primary field quickly diminishes with depth, its penetration depending on the separation between the transmitting and receiving coil, the transmission frequency, and the coil orientation (Mcneill, 1990).

In our case, the maximum sensitivity with an EM31 device ranges between 2 and $5 \mathrm{~m}$ depths. The reproducibility of readings at a single location was generally within $0.5 \mathrm{mS} / \mathrm{m}$. Each determination rounded to the nearest unit of $\mathrm{mS} / \mathrm{m}$ was entered by hand in the field on a Compaq Pocket PC connected to a Global Positioning System (GPS) receiver using ESRI® ArcPad software. These EM measurements were performed in April 2015 when dry season occurred in the study site to remove confounding issue of soil saturation on EM signal. 


\subsection{Analytical Methods}

\section{a. Sample Preservation}

Groundwater was collected from pre-existing tube wells with pipes open at the bottom in such a way as to exclude contact with the atmosphere. Samples for measurement of $\mathrm{Fe}^{2+}$ and $\mathrm{S}^{2-}$ were immediately collected with a syringe and filtered through a $0.22 \mu \mathrm{m}$ filter membrane directly into pre-prepared colorimetric reagent solutions. For anions, a $15 \mathrm{~mL}$ sample was filtered into clean amber plastic bottle. For DOC measurement, a filtered $20 \mathrm{~mL}$ sample was acidified with $0.25 \mathrm{~mL}$ of concentrated $\mathrm{HCl}(37 \%$, Sigma-Aldrich) into a special amber glass bottle. To measure major and trace elements, a filtered $15 \mathrm{~mL}$ sample was acidified with $0.25 \mathrm{~mL}$ of $65 \% \mathrm{HNO}_{3}$ (Merck, Suprapur). All samples were stored in a $4^{\circ} \mathrm{C}$ until analysis.

In addition to groundwater samples, core sediments of the borehole near Khanh An were collected at depths ranging from $0-20 \mathrm{~m}$ (Fig. 1). Solid samples were conserved under $\mathrm{N}_{2}$ flow using Mylar ${ }^{\circledR}$ bag and then stored at $+4^{\circ} \mathrm{C}$ until analysis. Sediments from depths of $7 \mathrm{~m}, 14 \mathrm{~m}$ and $16 \mathrm{~m}$ were characterized mineral compositions using X-ray diffraction (XRD) and As bearing minerals using X-ray synchrotron technique, in particular, X-ray absorption near edge structure (XANES).

\section{b. Analytical Techniques}

Temperature, $\mathrm{pH}$, electrical conductivity of water (EC) and dissolved oxygen (DO) were measured onsite using a WTW 340i multiparameter meter and a Hach sensION6 dissolved oxygen meter, respectively. Alkalinity was determined within $24 \mathrm{~h}$ using Gran titration in unit of $\mathrm{mg} \mathrm{HCO}_{3}^{-} / \mathrm{L}$ (Andersen, 2002). Samples for measurement of $\mathrm{Fe}^{2+}$ and $\mathrm{S}^{2-}$ were immediately analyzed colorimetrically with a Hach DR 2010 spectrophotometer. The determination of major $(\mathrm{Mg}, \mathrm{Ca}, \mathrm{Na}, \mathrm{K}$ ) and trace (As, $\mathrm{Fe}, \mathrm{Mn}, \mathrm{Ba}, \mathrm{Al}$ ) cations were performed by ICP - OES (Agilent 720-ES, Varian). Dissolved anions $\left(\mathrm{Cl}^{-}\right.$, $\left.\mathrm{F}^{-}, \mathrm{Br}^{-}, \mathrm{NO}_{2}, \mathrm{NO}_{3}{ }^{-}, \mathrm{PO}_{4}{ }^{3-}, \mathrm{SO}_{4}{ }^{2-}\right)$ were determined by ion chromatography using a Metrohm 761 Compact Ion Chromatograph with a detection limit of $0.1 \mathrm{mg} / \mathrm{l}$ and a precision better than $5 \%$. DOC concentration was measured using a Shimazu VCSN analyzer with a detection limit of $0.3 \mathrm{mg} / \mathrm{l}$ and a precision better than $2.5 \%$.

The major elements ( $\mathrm{Na}, \mathrm{K}, \mathrm{Mg}, \mathrm{Ca}, \mathrm{P}, \mathrm{Fe}, \mathrm{Mn}, \mathrm{Al}, \mathrm{S}$ and total $\mathrm{As})$ are identified using total acidic digestion $\left(\mathrm{HNO}_{3}+\mathrm{H}_{2} \mathrm{O}_{2}+\mathrm{HF}, \mathrm{H}_{3} \mathrm{BO}_{3}+\mathrm{HF}\right)$ and Inductively Coupled Plasma - Optical Emission Spectrometry (ICP-OES) (Agilent 720-ES, Varian). To avoid oxidation by air, samples were loaded into glass capillaries inside a glovebox $\left(\mathrm{O}_{2} \leqslant 10 \mathrm{ppm}\right)$ (Jacomex). For X-ray powder diffraction (XRD) analysis, the core samples were ground using a McCrone micronizing mill, and the resulting slurry freeze dried before being prepared as a randomly oriented mount. The clay mineralogy was determined on the $<2 \mu \mathrm{m}$ fraction. Following washing of soluble salts with pure water and removal of organic matter with $\mathrm{H}_{2} \mathrm{O}_{2}$, as described by (Moore \& Reynolds, 1997), this fraction was extracted by centrifugation. Oriented mounts were prepared by drying the resulting suspension onto glass slides. Ethylene glycol (EG) solvation of the slides was achieved by exposing them to EG vapor at $50{ }^{\circ} \mathrm{C}$ for a minimum of $12 \mathrm{~h}$. XRD patterns were recorded with a Bruker D5000/D8 powder diffractometer equipped with a SolX $\mathrm{Si}(\mathrm{Li})$ solid state detector from Baltic Scientific Instruments using $\mathrm{CuK \alpha} \_1+2$ radiation. Intensities were recorded from 5 to $90^{\circ}$ ( $5 \mathrm{~s}$ counting time per step) and from 2 to $50^{\circ}(4 \mathrm{~s}$ counting time per step) for bulk and clay mineralogy determination, respectively.

Arsenic speciation in the sediment samples was examined by XANES at the As K-edge $(11,867 \mathrm{eV})$ using the bending magnet beamline BM08 of the European Synchrotron Radiation Facility (ESRF, Grenoble, France). Samples were brought to the synchrotron facility in an anaerobic jar, mounted on the sample holders inside a glove box and then quickly transferred to the experimental chamber. To prevent beam-induced redox reactions or sample oxidation, all samples were measured in a high vacuum at low temperatures $(77 \mathrm{~K})$. Several As references were measured along with the sediment samples in transmission mode. At the As edge, a homemade As(0) standard (zero-valent arsenic nanoparticles, (Pal et al., 2012)) was measured in transmission mode simultaneously with the sample spectra for accurate energy calibration. All XANES spectra were calibrated, normalized, background subtracted and the relative contributions of the different As reference compounds calculated by linear combination fitting (LCF) using the ATHENA software package (Ravel \& Newville, 2005). LCF procedure first aimed at reproducing quantitatively all the features of the spectra, using the smallest number of components. Additional components were added only if the reduced chi-square $\left(\mathrm{X}_{\text {red }}^{2}\right)$ value is lower by at least $20 \%$, which was found to be the threshold for significantly improving the best fit. Contributions to the fits of 
fewer than $5 \%$ of the sum were not considered, in accordance with the error associated with the LCF procedure (Bardelli et al., 2011; Chakraborty et al., 2010; Isaure et al., 2002). Arsenic references included: (i) $\mathrm{NaAsO}_{2}$ and $\mathrm{NaHAsO}_{4}$ (Sigma-Aldrich), MTA(V) (monothioarsenate), DTA(V) (dithioarsenate) and TeTA(V) (tetrathioarsenate) prepared using the method optimized by Suess et al. (2012) (ii) the minerals $\mathrm{As}_{2} \mathrm{~S}_{3}, \mathrm{As}_{2} \mathrm{~S}_{5}, \mathrm{As}_{2} \mathrm{O}_{3}, \mathrm{As}_{2} \mathrm{O}_{5}, \mathrm{FeAsO}_{4}$ (scorodite) were commercial products (Fluka or Sigma - Alrich) and FeAsS (arsenopyrite), a natural sample was provided by the Natuaral Hystory museums of the University of Florence collected from Baccu Locci (Sardinia, Italy), (iii) the complexes of $\mathrm{As}(\mathrm{III})$ and $\mathrm{As}(\mathrm{V})$ sorbed onto goethite (Farquhar et al., 2002) and (iv) the thiol As(III) bound organic matter (OM) species: glutamyl-cysteinyl-glycinyl-thiolarsenite (As(III)-Glu) synthesized using the method of Raab et al., (2004) and Langner et al. (2011) (Langner et al., 2011; Raab et al., 2004).

\section{c. Thermodynamic Calculations}

Thermodynamic calculations were performed using the PHREEQC program (Parkhurst and Appelo, 1999). The database for As species was updated according to recent data reported in the literature (Helz and Tossell, 2008). The program solves mass balance and chemical reaction equations and evaluates the saturation index (SI) of minerals in groundwater. In the model, pH, cations, anions, alkalinity exchange to pressure of $\mathrm{CO}_{2}$ were used.

\section{Results}

\subsection{Groundwater Chemistry}

The Piper diagram plotted for 40 samples indicates that groundwater is predominantly of $\mathrm{Ca}^{-} \mathrm{HCO}_{3}^{-}$ type (Fig. 2a). Bicarbonate represents up to $80 \%$ in 38 samples except for 2 samples showing $70 \%$ of $\mathrm{Cl}^{-}$. A few groundwater samples are found to have distinct higher concentration of $\mathrm{Na}$ and $\mathrm{Cl}^{-}$. The $\mathrm{pH}$ values are neutral to slightly alkaline $(7.22 \pm 0.16)$. Alkalinity and $\mathrm{pH}$ measurements, combined with carbonic acid equilibria, lead to a $\mathrm{P}_{\mathrm{CO} 2}$ ranging from $10^{-1.92}$ to $10^{-1.17} \mathrm{~atm}$, with an average value of $10^{-1.54}$ atm. These results indicate additionally calcium-bicarbonate enrichment along with a sodiumbicarbonate and chloride types reported previously (Nguyen and Itoi, 2009). Other anions, in decreasing order of concentration, are $\mathrm{Cl}^{-}, \mathrm{NO}_{2}{ }^{-}$and $\mathrm{SO}_{4}{ }^{2-}$. $\mathrm{SO}_{4}{ }^{2-}$ concentration values are generally low ranging from 0.07 to $13 \mathrm{mg} \mathrm{L}^{-1}$. Sulfide concentration values were observed from $0-0.27 \mathrm{mg} \mathrm{L}^{-1}$. The low concentration of $\mathrm{SO}_{4}{ }^{2-}$ and the presence of sulfide tend to be associated with strongly reducing groundwater (Fig. 2a). One of the possible mechanisms to explain this observation could be related to bacterial reduction of sulfate operating in the aquifer. Total $\mathrm{PO}_{4}{ }^{3-}$ concentrations are lower than the detection limit. EC values in groundwater range from 474 to $1774 \mu \mathrm{S} / \mathrm{cm}$, which shows a slow salinity in the shallow aquifer.

For major cations, $\mathrm{Ca}^{2+}$ concentration is rather constant through the aquifer, with an average concentration of $82 \pm 20 \mathrm{mg} \mathrm{L} \mathrm{L}^{-1}$. The groundwater is roughly at equilibrium with calcite, representing with a saturation index (SI) ranging from -0.48 to +0.78 , and an average value of +0.18 . Other cations, in decreasing order of concentration, are $\mathrm{Na}^{+}, \mathrm{Mg}^{2+}, \mathrm{K}^{+}, \mathrm{Fe}^{2+}$ and $\mathrm{Mn}^{2+}$ (Table 1). The groundwater is very hard; with an average hardness of $306 \mathrm{mg}$ and minimum average of $182 \mathrm{mg}$ equivalent $\mathrm{CaCO}_{3} \mathrm{~L}^{-1}$ based on the sum of $\mathrm{Ca}^{2+}$ and $\mathrm{Mg}^{2+}$ concentrations. Fig 2.b shows the groundwater is in equilibrium and slightly supersaturated with respect to both calcite and dolomite, which was found similar to the trend that was reported to occur in Bangladesh and West Bengal (Nickson et al., 2000).

\subsection{Distribution of Arsenic Hotspots in Groundwater}

The distribution of As concentrations corresponding to location of groundwater in An Phu is shown in Fig. 2. Samples were collected at depth of $12-40 \mathrm{~m}$. Total dissolved As concentrations between 102 and $1270 \mu \mathrm{g} / \mathrm{L}, 10$ - 127 times higher than WHO's guideline for As in drinking water, was observed (Table 1). These results suggest that all of samples are contaminated by As in Khanh An shallow aquifer. The maximum As levels appear in several wells nearest to the River in the north-eastern area where dissolved oxygen (DO) is at a very low level of $0.62-0.94 \mathrm{mg} / \mathrm{L}$. The significant Fe concentrations are detected at most areas nearest the River. The dissolution and fixation of As depend on dissolution and precipitation of Fe, controlled by the change in redox conditions with depth (Nguyen and Itoi, 2009). 
The processes causing changes in iron redox chemistry are important since they can affect the mobility of arsenic. One of the causes of high arsenic concentration is reductive dissolution of hydrous $\mathrm{Fe} / \mathrm{Mn}$ oxides and/or release As-bearing minerals.

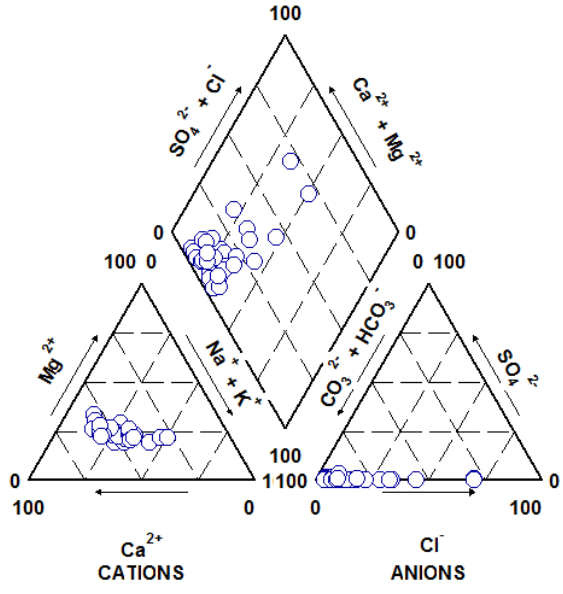

(a)

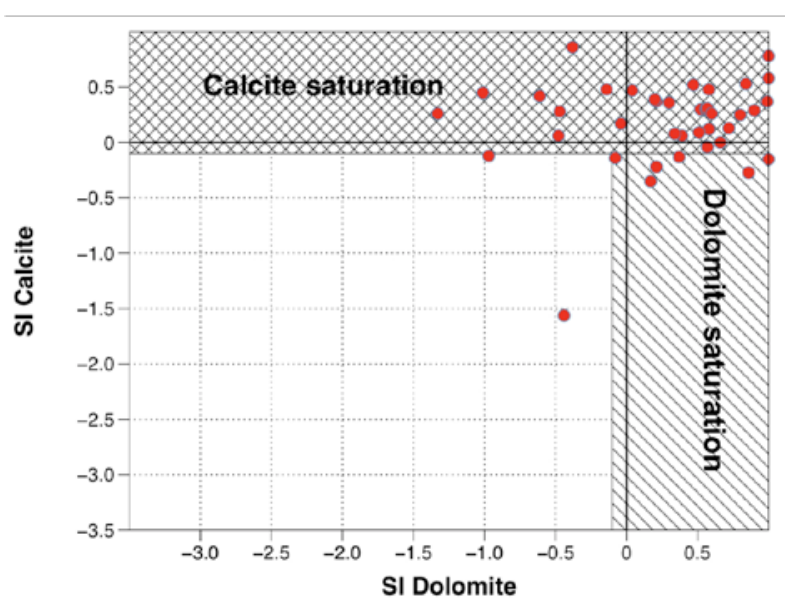

(b)

Figure 2. (a) The major ion composition of groundwater samples plotted on Piper diagram and (b) The groundwater is in equilibrium and slightly supersaturated with Calcite and Dolomite.

Table 1. Chemical composition of groundwater

\begin{tabular}{|c|c|c|c|c|c|c|c|c|c|c|c|c|c|c|c|c|c|c|c|c|}
\hline ID & $\frac{\text { Depth }}{\text { (m) }}$ & pH & $\begin{array}{c}\mathbf{E C} \\
\mu \mathrm{S} / \mathrm{cm}\end{array}$ & DO & DOC & $\begin{array}{c}\text { HS- } \\
(\text { (1g/L) }\end{array}$ & Fe & Mn & As & $\mathrm{Na}^{+}$ & $\overline{\mathbf{K}^{+}}$ & $\mathbf{M g}^{2+}$ & $\mathrm{Ca}^{2+}$ & $\mathrm{HCO}_{3}^{-}$ & $\mathbf{F}$ & CI & $\mathrm{NO}_{2}^{-}$ & $\mathbf{B r}^{-}$ & $\mathrm{NO}_{3}^{-}$ & $\mathrm{SO}_{4}{ }^{2}$ \\
\hline KA V1 & 25 & 711 & 841 & 0.74 & 5.89 & 4.00 & 950 & 0.77 & 1.02 & 31.02 & 5.69 & 23.11 & 77.70 & 43496 & 0.09 & 3758 & 12.42 & 134 & 0.03 & 023 \\
\hline KA V2 & 36 & 709 & 805 & 0.94 & 1355 & 0.42 & 13.07 & 034 & 1.19 & 2156 & 7.07 & 34.15 & 9191 & 537.00 & 0.07 & 16.86 & 14.87 & 1.83 & 0.02 & 0.17 \\
\hline KA V3 & 25 & 701 & 888 & 0.62 & 999 & 6.71 & 15.08 & 0.37 & 1.26 & 20.12 & 550 & 24.40 & 74.16 & 484.62 & 0.08 & 1456 & 13.89 & 1.40 & 0.03 & 0.17 \\
\hline KA V4 & 33 & 728 & 787 & 190 & 733 & 0.00 & 2.12 & 135 & 0.44 & 28.88 & 4.61 & 24.89 & 80.31 & 519.83 & 0.10 & 1491 & 10.61 & 125 & 0.10 & 036 \\
\hline KA VS & 23 & 737 & 975 & 1.72 & 6.66 & 0.66 & 022 & 0.62 & 0.43 & 46.11 & 6.83 & 26.15 & 79.45 & 536.60 & 0.11 & 3955 & 13.71 & 136 & 0.06 & 020 \\
\hline KA Vo & 30 & 718 & 936 & 130 & 7.75 & 0.00 & 4.12 & 198 & 0.47 & 3621 & 6.04 & 2437 & 8838 & 537.19 & 0.08 & 25.65 & 1429 & 131 & 0.23 & 026 \\
\hline KA V7 & 40 & 718 & 1144 & 150 & 1638 & 1.16 & 3.69 & 020 & 1.02 & 55.14 & 7.12 & 3493 & 88.84 & 60422 & 0.08 & 7158 & 1531 & 2.08 & 021 & 028 \\
\hline KA V8 & 40 & 707 & 1033 & 090 & 958 & 857 & 14.82 & 0.49 & 127 & 39.89 & 7.16 & 27.04 & 85.03 & 598.14 & 0.09 & 34.62 & 1522 & 156 & 0.16 & 0.19 \\
\hline KA V9 & 28 & 707 & 738 & 1.72 & 3.14 & 153 & 932 & 129 & 0.64 & 49.12 & 3.72 & 17.74 & 7956 & 357.82 & 0.07 & 45.73 & 9.44 & 129 & 0.12 & 057 \\
\hline KA V10 & 20 & 720 & 708 & 151 & 2.69 & 326 & 7.11 & 096 & 059 & 4132 & 4.07 & 2023 & 73.40 & 439.40 & 0.10 & 3056 & 983 & 121 & 0.09 & 1.84 \\
\hline KA V11 & 20 & 727 & 775 & 1.88 & 3.75 & 1.40 & 129 & 1.46 & $0 \leq 52$ & 58.27 & 4.00 & 18.76 & 78.12 & 445.77 & 0.00 & 4527 & 000 & 0.00 & 0.00 & 0.07 \\
\hline KA V12 & 22 & 708 & 622 & 1.72 & 3.71 & 0.42 & 652 & 1.02 & 0.60 & 21.47 & 2.85 & 19.16 & 7132 & 389.61 & 0.08 & 30.80 & 911 & 022 & 0.40 & 020 \\
\hline KA V13 & 23 & 712 & 770 & 156 & 4.43 & 0.42 & 8.11 & 157 & 0.48 & 20.47 & 2.04 & 13.62 & 52.60 & 32533 & 0.06 & 36.69 & 10.00 & 031 & 031 & 0.14 \\
\hline KA V14 & 25 & 714 & 1248 & 1.69 & 5.45 & 0.79 & 11.18 & 123 & 0.89 & 8422 & 638 & 3033 & 109.61 & 546.03 & 0.07 & 163.07 & 11.42 & 0.73 & 058 & 0.07 \\
\hline KA V15 & 24 & 722 & 770 & 2.02 & 4.63 & 202 & 4.01 & 0.63 & 0.86 & 5351 & 494 & 19.88 & 6822 & 51956 & 0.10 & 21.66 & 11.49 & 0.25 & 020 & 0.13 \\
\hline KA Y16 & 27 & 726 & 679 & 2.15 & 290 & 054 & 191 & 125 & 0.61 & 40.61 & 458 & 19.72 & 66.84 & 446.15 & 0.07 & 19.10 & 10.00 & 020 & 0.13 & 020 \\
\hline KA V17 & 32 & 722 & 1007 & 0.74 & 894 & 0.91 & 1.89 & 0.18 & 1.08 & 5028 & 6.09 & 26.80 & 89.40 & 474.44 & 0.09 & 40.27 & 1422 & 0.54 & 0.17 & 0.41 \\
\hline KA Y18 & 40 & 699 & 474 & 1.81 & 1.64 & 190 & 8.74 & 038 & 0.74 & 3520 & 3.61 & 22.82 & 8450 & 426.76 & 0.08 & 1139 & 6.73 & 0.13 & 0.22 & 4.11 \\
\hline KA V19 & 25 & 728 & 610 & 2.15 & 3.06 & 1.40 & 2.89 & 152 & 0.46 & 3958 & 332 & 16.78 & 5999 & 39094 & 0.11 & 1138 & 896 & 0.15 & 0.03 & 2.81 \\
\hline KA V20 & 25 & 723 & 1365 & 134 & 6.12 & 153 & 0.06 & 0.81 & 059 & 12859 & 8.02 & 29.85 & 96.85 & 792.21 & 0.07 & 186.80 & 11.67 & 0.82 & 0.04 & 023 \\
\hline KA Y 21 & 22 & 726 & 733 & 194 & 430 & 0.54 & 0.78 & 1.44 & 0.73 & 54.40 & 4.60 & 17.45 & 6352 & 429.88 & 0.09 & 18.17 & 906 & 021 & 0.13 & 021 \\
\hline KA V 22 & 28 & 7.44 & 1057 & 197 & 427 & 0.91 & 0.18 & 095 & 0.45 & 8192 & 6.40 & 27.77 & 83.83 & 32120 & 0.10 & 9058 & 1211 & 0.45 & 0.04 & 0.34 \\
\hline KA V 23 & 28 & 716 & 831 & 250 & 4.63 & 0.17 & 531 & 026 & 0.88 & 36.16 & 4.53 & 24.65 & 83.64 & 430.40 & 0.07 & 1793 & 11.85 & 023 & 0.07 & 024 \\
\hline KA V24 & 24 & 727 & 757 & 090 & 538 & 128 & 254 & 092 & 0.90 & 53.79 & 4.70 & 2130 & 6627 & 432.06 & 0.08 & 25.73 & 10.47 & 025 & 0.04 & 0.92 \\
\hline KA V25 & 24 & 709 & 649 & 1.75 & 436 & 0.17 & 1.17 & 0.17 & 0.61 & 39.00 & 392 & 1522 & 47.82 & 467.67 & 0.10 & 11.41 & 935 & 0.15 & 0.08 & 0.40 \\
\hline KA V26 & 24 & 7.41 & 1015 & 2.47 & 457 & 0.42 & 0.41 & 0.65 & 0.42 & 73.67 & 6.07 & 25.42 & 8056 & 452.85 & 0.12 & 77.77 & 1124 & 0.41 & 0.04 & 033 \\
\hline KA Y27 & 27 & 708 & 522 & 197 & 1.70 & 4.74 & 4.47 & 0.35 & 0.51 & 2729 & 2.03 & 16.67 & 51.45 & 30590 & 0.07 & 13.63 & 730 & 0.13 & 0.15 & 3.71 \\
\hline KA V 28 & 20 & 726 & 1068 & 1.09 & 7.67 & 1.16 & 4.12 & 0.41 & 0.86 & 6994 & 639 & 2234 & 80.65 & 596.69 & 0.09 & 28.42 & 14.01 & 0.60 & 0.03 & 029 \\
\hline KA V29 & 31 & 733 & 1110 & 1.06 & 5.08 & 227 & 0.87 & 0.75 & 1.08 & 7331 & 650 & 2899 & 85.67 & 52028 & 0.08 & 50.18 & 1201 & 0.59 & 0.10 & 029 \\
\hline KA V 30 & 24 & 737 & 1069 & 2.44 & 5.65 & 3.01 & 0.10 & 0.74 & 0.84 & 6424 & 6.03 & 29.27 & 7939 & 594.49 & 0.06 & 3552 & 13.11 & 0.55 & 0.05 & 020 \\
\hline KA Y31 & 12 & 699 & 1432 & 1.02 & 495 & 536 & 2159 & 333 & 0.58 & 62.81 & 638 & 36.89 & 14595 & 632.86 & 0.06 & 18439 & 000 & 199 & 0.00 & 028 \\
\hline KA V 32 & 12 & 7.41 & 910 & 152 & 5.00 & 2.02 & 0.06 & 1.62 & 0.10 & 3154 & 598 & 28.42 & 92.42 & 429.46 & 0.08 & 2859 & 12.69 & 1.41 & 10.47 & 13.00 \\
\hline KA V 33 & 18 & 716 & 963 & 2.09 & 3.66 & 0.00 & 3.03 & 3.44 & 0.32 & 46.53 & 439 & 2632 & 111.64 & 49996 & 0.07 & 30.64 & 1154 & 0.23 & 0.02 & 3.41 \\
\hline KA V34 & 22 & 701 & 1637 & 230 & 333 & 1.40 & 3.70 & 3.45 & 0.16 & 115.74 & 5.46 & 3638 & 13390 & 339.72 & 0.06 & 467.13 & 721 & 097 & 0.00 & 4.71 \\
\hline KA V 35 & 30 & 725 & 1125 & 225 & 4.43 & 338 & 156 & 0.12 & 0.89 & 103.07 & 725 & 2550 & 61.15 & 363.72 & 0.08 & 17054 & 10.59 & 0.64 & 0.13 & 0.17 \\
\hline KA V36 & 32 & 702 & 1774 & 1.43 & 7.10 & 3.01 & 4.88 & 0.15 & 0.71 & 17998 & 8.18 & 41.67 & 86.83 & 372.63 & 0.12 & 50457 & 7.75 & 131 & 0.00 & 028 \\
\hline KA V3? & 30 & 764 & na & 299 & 2.70 & 091 & 826 & 2.48 & 0.55 & 23.65 & 4.45 & 22.41 & 81.72 & 528.67 & 0.10 & 14.01 & 1031 & 0.13 & 0.04 & 1.08 \\
\hline KA V38 & 25 & 7.47 & na & 1.09 & 34.07 & 0.00 & 851 & 2.11 & 0.63 & 62.66 & 533 & 25.86 & 10431 & 460.89 & 0.09 & 103.74 & 11.13 & 0.47 & 0.19 & 0.59 \\
\hline KA V39 & 21 & 758 & na & 1.02 & 6.61 & 0.00 & 951 & 030 & 0.86 & 3236 & 5.58 & 24.74 & 87.43 & 54222 & 0.07 & 1121 & 1201 & 025 & 3.01 & 022 \\
\hline KA V40 & 25 & 714 & 598 & 151 & 3.12 & 289 & 3.75 & 0.80 & 0.48 & 47.89 & 326 & 15.60 & 5027 & 338.89 & 0.15 & 4521 & 6.73 & 026 & 0.02 & 1.11 \\
\hline
\end{tabular}

n.a: not analyzed

Concentrations in mg/l except as noted 


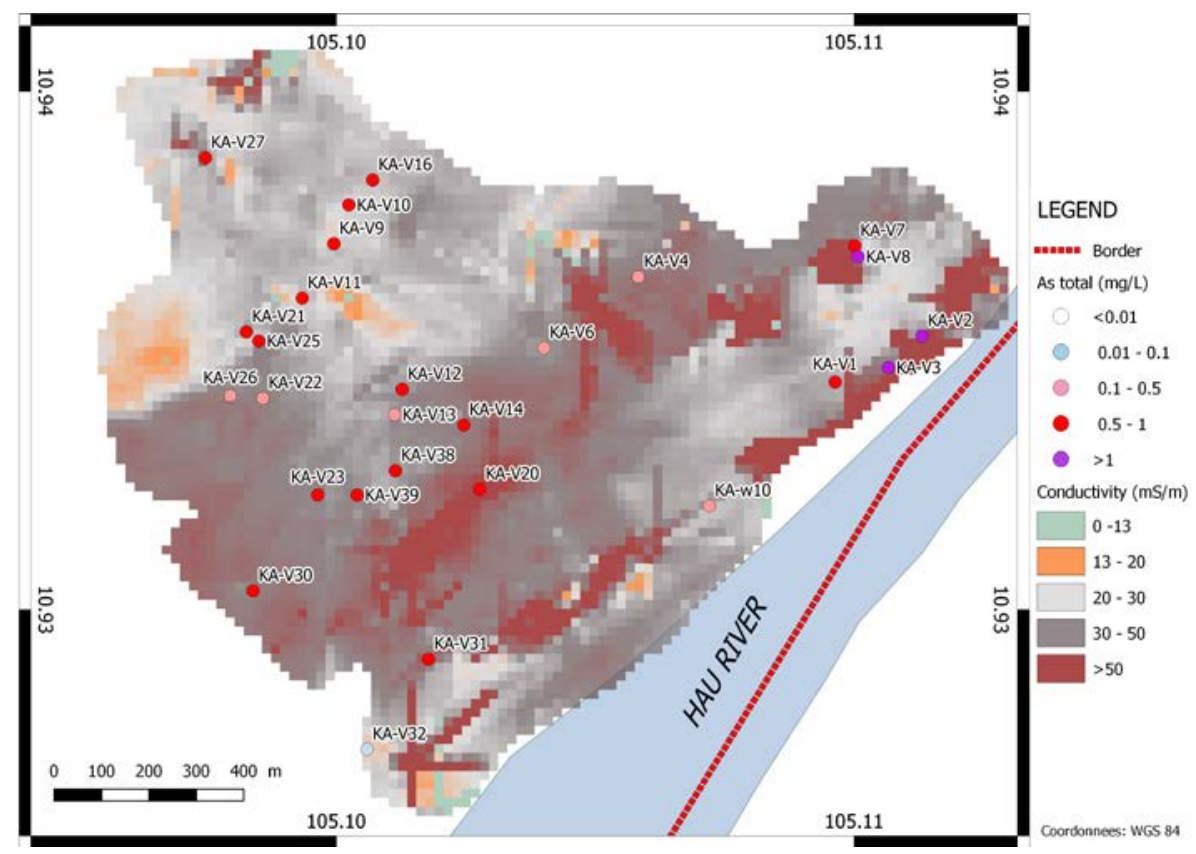

Figure 3. Map showing as concentrations and the electrical conductivity data distribution using EM31 device in An Phu district.

\subsection{Distribution of Electrical Conductivity}

Electrical conductivities measured in open areas span a wide range of 15 to $200 \mathrm{mS} / \mathrm{m}$, with an average value of $48 \mathrm{mS} / \mathrm{m}(\mathrm{n}=66,646)$ (Fig. 3). The histogram of EM conductivities tends toward high values at nearly $99 \%$ of measurements and is in the $20-150 \mathrm{mS} / \mathrm{m}$ range. The high conductivity values exceeding more than $100 \mathrm{mS} / \mathrm{m}$ are found along the roadside where most villages are located, with shallow wells that consistently reach groundwater with high concentration of As. Most of conductivity values for our studied site are around 40 to $50 \mathrm{mS} / \mathrm{m}$, which indicates the presence of thick sticky clay layer in the soil. Values for EM conductivity allow distinguishing between permeable (EM $<30 \mathrm{mS} / \mathrm{m}$ ) and impermeable $(\mathrm{EM}>30 \mathrm{mS} / \mathrm{m})$ surface layers. The majority of crops grow in low EC fields and are corn, rice, and chili. Thus, the data establish the local heterogeneity with sandy soils on the west and sticky clay along the River (Fig. 3).

\subsection{Thermodynamic Modeling}

Table 2 summarizes the calculated SI values of different mineral phases in Khanh An groundwater. Fe and Mn (hydr)oxides, clay minerals and organic matter play a role in regulating As concentration. Based on PHREEQC calculation, Fe (oxyhydr)oxide minerals, such as ferrihydrite (Charlet et al., 2011), goethite (Asta et al., 2009), magnetite (Guo et al., 2007a), natural/synthetic siderite (Charlet et al., 2011; Guo et al. 2011; Guo et al., 2007b; Wolthers et al., 2005) may form and then adsorb relatively large amounts of As. Mn oxides have been documented to significantly affect As adsorption (Ghosal et al., 2014; McArthur et al., 2004). In reducing conditions, As-sorbed onto Mn oxides is released, which is more favorable than $\mathrm{Fe}$ (oxyhydr)oxides reduction (Kelly et al., 2005). Calcite $\left(\mathrm{CaCO}_{3}\right)$ is also slightly oversaturated in most samples. The adsorption and co-precipitation mechanisms were investigated to determine which As species can be incorporated in bulk $\mathrm{CaCO}_{3}$ by substitution at $\mathrm{CO}_{3}^{2-}$ sites (Fernández-Martínez et al., 2006; Román-Ross et al., 2006; SØ et al., 2008). Although two samples are at equilibrium with siderite $\left(\mathrm{FeCO}_{3}\right)$, the sorptive capacity of siderite towards $\mathrm{As}$ is as low as $0.28 \mathrm{~L} \mathrm{~g}^{-1}$ of $\mathrm{As}(\mathrm{III})$ and $3.36 \mathrm{~L} \mathrm{~g}^{-1}$ of $\mathrm{As}(\mathrm{V})$ at $\mathrm{pH} 7$ (Charlet et al., 2011; Wolthers et al., 2005). Therefore, iron 
(oxyhydr)oxides and carbonate clay minerals may represent an important component of the As cycle in the aquifer sediments.

Table 2. Saturation index of difference minerals in groundwater computed using PHREEQC.

\begin{tabular}{|c|c|c|c|c|c|c|c|c|c|c|c|}
\hline ID & $\begin{array}{l}\text { Siderite } \\
\text { FeCO }_{3}\end{array}$ & $\begin{array}{l}\text { Dolonite } \\
\text { Ca,Mg)CO}_{3}\end{array}$ & $\mathrm{MnCO}_{3}$ & $\mathrm{CaCO}_{3}$ & $\mathrm{Fe}(0 \mathrm{OH})_{3}$ & $\begin{array}{l}\text { Gibbsite } \\
\text { Al(OH) } 3\end{array}$ & $\begin{array}{l}\text { Goethite } \\
\text { FeoOII }\end{array}$ & $\begin{array}{c}\text { Hansmannite } \\
\mathrm{Mm}_{3} \mathrm{O}_{4}\end{array}$ & $\begin{array}{c}\text { Healite } \\
\mathrm{Fe}_{2} \mathrm{O}_{3}\end{array}$ & Jarosite & $\begin{array}{c}\text { Pyrolnsite } \\
\mathrm{MnO}_{2}\end{array}$ \\
\hline KA V2 & -5.79 & 0.58 & 0.18 & 0.30 & 3.800 & 1.250 & 9.690 & 2.340 & 21.400 & -1.710 & 4960 \\
\hline KA V4 & -6.70 & 0.72 & 0.92 & 0.47 & 3.090 & 0.830 & 8.980 & 5.250 & 19.970 & -4.180 & 5.900 \\
\hline KA V5 & -7.69 & 0.21 & 0.11 & 0.13 & 2.110 & 0.660 & 8.010 & 2.980 & 18.040 & -8.580 & 5.060 \\
\hline KA V6 & 1.27 & 0.56 & 1.01 & 037 & 2.740 & 1.010 & 8.640 & 2.270 & 19.280 & -5.030 & -5.750 \\
\hline KA V9 & -6.07 & -0.97 & -0.11 & -0.35 & 3.620 & 1.010 & 9.520 & 1.940 & 21.060 & -2.560 & 4.750 \\
\hline KA V10 & -6.17 & -0.47 & 0.11 & -0.12 & 3.570 & 0.720 & 9.460 & 2.750 & 20.940 & -1.970 & 5.000 \\
\hline KA V11 & -6.98 & 0.39 & 0.90 & 0.28 & 2.860 & 0.890 & 8.750 & 5.250 & 19.500 & -5.850 & 5900 \\
\hline KA V12 & -6.23 & -0.08 & 0.56 & 0.06 & 3.500 & 0.970 & 9.390 & 3.940 & 20.790 & -2.930 & 5.490 \\
\hline KA V13 & -6.23 & -0.44 & 0.73 & -0.14 & 3.600 & 0.960 & 9.490 & 4.690 & 20.990 & -3.050 & 5.730 \\
\hline KA V14 & -5.87 & -1.33 & 0.77 & -1.56 & 3.760 & 1.020 & 9.650 & 4.300 & 21.300 & -2.670 & 5590 \\
\hline KA V19 & -6.68 & -1.01 & 0.92 & 0.17 & 3.210 & 0.770 & 9.100 & 5.470 & 20.200 & -1.910 & 5.960 \\
\hline KA V20 & -8.08 & 0.80 & 0.65 & 0.45 & 1.500 & 0.950 & 7.390 & 3.730 & 16.790 & -8.600 & 5.440 \\
\hline KA V21 & -7.22 & 0.20 & 0.86 & 0.25 & 2.640 & 0.760 & 8.540 & 5.320 & 19.080 & -5.770 & 5920 \\
\hline KA V22 & -8.08 & 0.66 & 0.76 & 0.39 & 2.050 & 0.620 & 7.940 & 5.790 & 17.880 & -7.620 & 6.060 \\
\hline KA V 23 & -632 & 0.34 & 1.31 & 0.00 & 3.390 & 1.070 & 9.280 & 5.760 & 20.570 & -2.830 & 6.130 \\
\hline KA V24 & -6.70 & 0.37 & 0.68 & 0.08 & 3.120 & 0.830 & 9.010 & 4.340 & 20.040 & -2.830 & 5.620 \\
\hline KA V25 & -6.91 & -0.14 & -0.13 & -0.13 & 2.730 & 1.050 & 8.630 & 1.400 & 19.260 & -4.310 & 4.680 \\
\hline KA V26 & -7.55 & 0.86 & 0.67 & 0.48 & 2.400 & 0.660 & 8.300 & 4.970 & 18.600 & -6.470 & 5.790 \\
\hline KA V27 & -6.51 & -0.61 & -0.03 & -0.27 & 3.320 & 0.930 & 9.210 & 2.410 & 20.420 & -0.900 & 4980 \\
\hline KA V 28 & -637 & 0.58 & 0.37 & 0.42 & 3.360 & 0.870 & 9.250 & 3.410 & 20.510 & -3.150 & 5310 \\
\hline KA V29 & -7.13 & 0.84 & 1.48 & 0.48 & 2.710 & 0.810 & 8.600 & 7.060 & 19.210 & -5.300 & 6.500 \\
\hline KA V30 & -8.02 & 0.99 & 1.51 & 0.53 & 1.800 & 0.720 & 7.690 & 7.070 & 17.390 & -8.350 & 6.510 \\
\hline KA V31 & 1.61 & 0.47 & 1.00 & 0.37 & -0.99 & 1.13 & 4.90 & -19.67 & 11.81 & -15.51 & -6.00 \\
\hline KA V40 & -6.52 & -0.27 & 0.47 & -0.15 & 3.270 & 1.02 & 9.16 & 3.80 & 20.33 & -2.15 & 5.42 \\
\hline
\end{tabular}

\subsection{Mineral Composition of Core Samples}

From the total digestion and XRD analyses of core samples, more than $30 \%$ of total mineral mass in the sediments is present as micas. Once buried in anoxic conditions, micas can adsorb As in the presence of $\mathrm{Fe}^{2+}$ and transform As and other pollutants into less toxic forms (Charlet et al., 2007). Pyrite is identified in all three layers of core samples, while gypsum is detected at the depth of $7 \mathrm{~m}$ and siderite is found at $16 \mathrm{~m}$ deep sediment. Low $\mathrm{SO}_{4}{ }^{2-}$ concentration and high pyrite content in sediment demonstrate that pyrite formation occurs under the reducing condition in the aquifer.

In addition, the bulk As speciation was also determined by X-ray adsorption near-edge spectroscopy (XANES) at the European synchrotron research facility (ESRF). XANES spectra show two absorption maximum peaks at 11,869 and $11,875 \mathrm{eV}$, including $\mathrm{As}(\mathrm{III})$ and $\mathrm{As}(\mathrm{V})$ speciation (Fig. 4a). The Obound As species, $\mathrm{As}(\mathrm{V})$ and $\mathrm{As}(\mathrm{III})$ sorbed onto goethite/ferrihydryrite were used in LCF. While $\mathrm{As}_{2} \mathrm{~S}_{3}$, thiol-bound As(III) and FeAsS were used for S-bound As(III). However, since the XANES of these species spectra are very similar and good matches with the sediments were obtained. LCF did not allow to discriminate the actual association of As between these S-bound As(III) species. For this reason, the best LCF results of the three layers (7, 14 and $16 \mathrm{~m}$ deep sediments) are summarized grouped in Fig. $4 \mathrm{~b}$. 
The results of the LCF performed in the $7 \mathrm{~m}$ deep layer sediment indicates that As(V) adsorbed onto iron (oxyhydr)oxides represents the main species with $61 \%$ of the total solid As, along with thiol-bound $\mathrm{As}(\mathrm{III})$ or $\mathrm{As}_{2} \mathrm{~S}_{3}(29 \%)$ and $\mathrm{As}(\mathrm{III})$ adsorbed onto (oxyhydr)oxides (13\%) (Fig. 4b). In the deeper (14 m layer) sediment, $61 \%$ of the total As species are S-bound As. The remaining O-bound As species are $33 \%$ $\mathrm{As}(\mathrm{V})$ and $12 \% \mathrm{As}(\mathrm{III})$. Thiol-bound $\mathrm{As}(\mathrm{III})$ and/or FeAsS accounted for $31 \%$ of total As in the $16 \mathrm{~m}$ deep sediment which was also reported in Mekong Delta, Cambodia (Stuckey et al., 2015, Wang et al., submitted). The O-bound As species are $43 \%$ and $29 \%$ for $\mathrm{As}(\mathrm{V})$ and $\mathrm{As}(\mathrm{III})$, respectively.
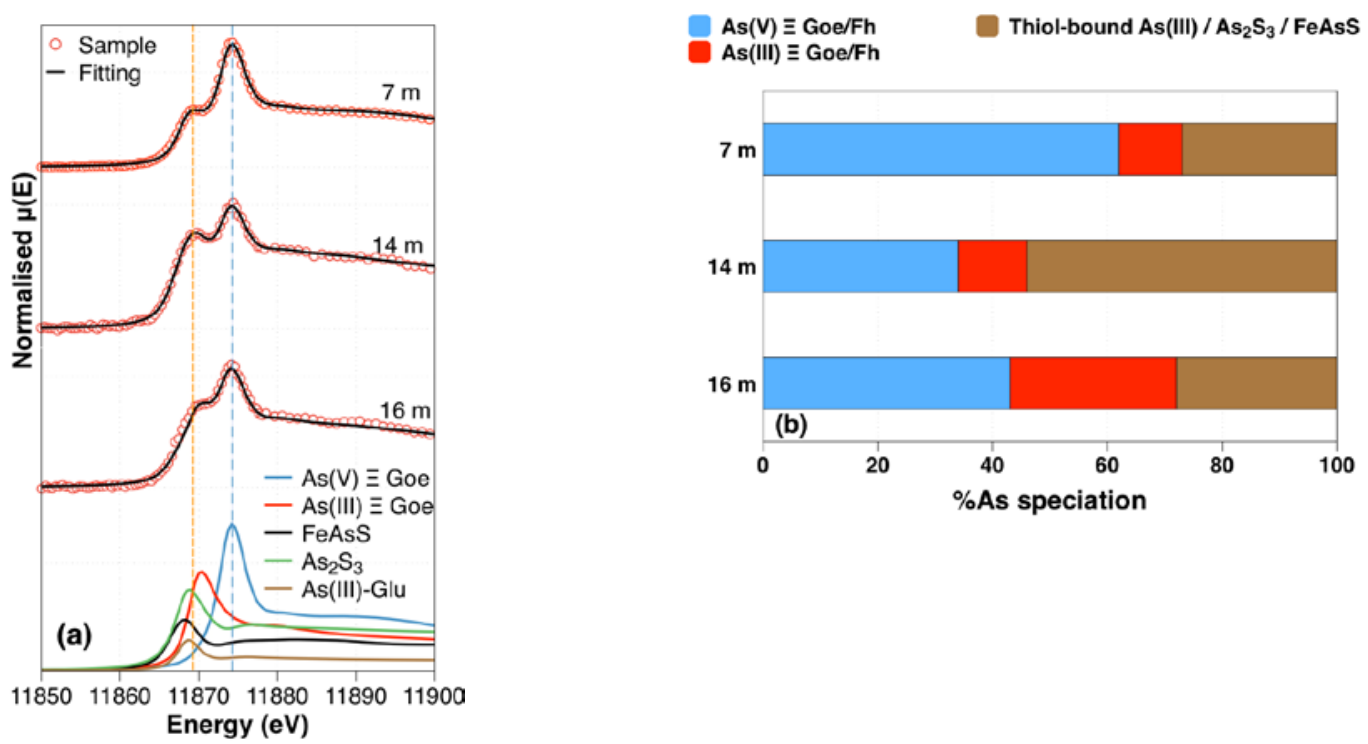

Figure 4. (a) Normalized As K-edge XANES spectra of sediment samples collected at 7, 14 and $16 \mathrm{~m}$ deep sediments and (b) Proportion of As solid phases as revealed LCF performed on corresponding XANES spectra, the error on the percentages is estimates to be in the around 10\% (Bardelli et al., 2011; Isaure et al., 2002). The spectra of the samples (red circles) are reported together with the LCF curves superimposed (solid lines). The spectra of the reference compounds used for LCF $(\mathrm{As}(\mathrm{III}) /(\mathrm{V}) \equiv \mathrm{Goe} / \mathrm{Fh}, \mathrm{FeAsS}, \mathrm{As} 2 \mathrm{~S} 3 \neg$, As(III)-Gluthiatone) are also shown..

\section{Discussion}

\subsection{Water Chemistry and As Concentration}

The liberation of As often happens by reductive dissolution of iron (oxyhydr)oxides that contains As bearing forms. One problem of reductive dissolution theory is how the reductant contacts the iron (oxyhydr)oxides. Groundwater recharge is composed of both surface water rich in organic matter, which enters the aquifer all year around and rainwater, which enters the aquifer from June to November. In our data, the groundwater concentration of dissolved organic $\mathrm{C}$ is generally high $(1.7-34 \mathrm{mg} \mathrm{C} / \mathrm{L})$, with an average concentration of $6.3 \mathrm{mg} \mathrm{C} / \mathrm{L}$. Concentrations of As correlates poorly with concentrations of dissolved Fe but correlate better with concentration of $\mathrm{HCO}_{3}{ }^{-} \cdot \mathrm{Fe}^{2+}$ concentrations do not remain constant, probably because it may precipitate as $\mathrm{FeCO}_{3}$. Samples with high concentrations of $\mathrm{Fe}^{2+}$ and $\mathrm{HCO}_{3}{ }^{-}$are oversaturated with $\mathrm{FeCO}_{3}$ representing with SI of 1.3 and 1.6 in $\mathrm{KA}$ V6 and $\mathrm{KA}$ V31, respectively, and most other samples are slightly oversaturated with calcite, dolomite $(\mathrm{Ca}, \mathrm{Mg}) \mathrm{CO}_{3}$ and $\mathrm{MnCO}_{3}$ (Table. 2). Reactive transport modeling suggest the precipitation of siderite to be a reasonable option in the Red River deltaic sediment in Vietnam (Postma et al., 2007). Moreover, siderite was identified at the $16 \mathrm{~m}$ deep sediment in a low organic matter layer sediment which was also found by Wang et al. (in submitted) (Wang et al., submitted). Under low DO conditions, Fe oxides are likely being reductively dissolved by soluble organic matter, resulting in the groundwater recharge becoming enriched in $\mathrm{Fe}^{2+}$ and $\mathrm{HCO}_{3}^{-}$(Appelo et al., 2002; Charlet et al., 2007; Nickson et al., 2000) following the equations below: 


$$
\begin{gathered}
\mathrm{O}_{2}+\mathrm{CH}_{2} \mathrm{O} \rightarrow \mathrm{H}^{+}+\mathrm{HCO}_{3}^{-} \\
\equiv \mathrm{FeH}_{2} \mathrm{AsO}_{4}+\mathrm{H}_{2} \mathrm{O} \rightarrow \equiv \mathrm{OH}+2 \mathrm{H}^{+}+\mathrm{Fe}^{2+} \mathrm{HAsO}_{4}{ }^{2-} \\
\equiv \mathrm{FeH}_{2} \mathrm{AsO}_{4}+3 \mathrm{H}_{2} \mathrm{O}+\mathrm{CH}_{2} \mathrm{O}+\mathrm{CaCO}_{3} \rightarrow \equiv \mathrm{OH}+6 \mathrm{H}^{+}+\mathrm{Fe}^{2+} \mathrm{HAsO}_{4}{ }^{2-}+2 \mathrm{HCO}_{3}+\mathrm{Ca}^{2+}+4 \mathrm{e}^{-}
\end{gathered}
$$

The solid phase As speciation along defined recharge pathway was identified as the As-bearing iron (oxyhydr)oxide phases in the Mekong Delta (Stuckey et al., 2015). In the process shown above, soluble $\mathrm{Fe}$ (oxyhydr)oxides and As bearing iron minerals release into groundwater both $\mathrm{Fe}^{2+}$ and $\mathrm{As}$, as documented in several previous studies (Hoang et al., 2010; Nguyen \& Itoi, 2009). However, As concentration was not associated with total iron concentration in most of groundwater samples. The results also indicate that appreciable As-bearing $\mathrm{Fe}(\mathrm{III})$ oxides (goethite and hematite) exist in the subsoil of An Phu. Furthermore, Arsenian pyrite (FeAsS) formation reported previously in Mekong deltaic in Vietnam and Cambodia (Stuckey et al., 2015; Wang et al., submitted) which would be a detectable source of As to groundwater only if FeAsS are oxidized. However, concentrations of $\mathrm{SO}_{4}{ }^{2-}$ are low and indicate reduction and possibly pyrite formation, rather than oxidation. The present data suggest that total cations concentrations of $\mathrm{Fe}, \mathrm{Ca}, \mathrm{Mn}$ and $\mathrm{Mg}$ concentrations correlate positively with $\mathrm{HCO}_{3}^{-}$concentration, indicating that simple mineral dissolution dominates the groundwater. In addition to redox processes, competition for adsorption sites at mineral surfaces (e.g., Fe/Mn (oxyhydr)oxides, clay minerals and weathered mica) may also act to mobilize As in groundwater containing high amounts of $\mathrm{HCO}_{3}^{-}$(Appelo et al., 2002; Charlet et al., 2007). The displacing effect of $\mathrm{HCO}_{3}^{-}$may offer an explanation for high As concentrations in Khanh An's aquifers, given that high $\mathrm{pH}$ and alkalinity values with average value of $7.8 \mathrm{mmol} \mathrm{L} \mathrm{L}^{-1}$, as a consequence of high $\mathrm{CO}_{2}$ partial pressures in the aquifer.

Another theory relates the liberation of As release to oxidation of pyrite which may contain arsenic to form jarosite (Nguyen \& Itoi, 2009):

$$
\begin{gathered}
\mathrm{FeS}_{2}+\mathrm{O}_{2}+\mathrm{H}_{2} \mathrm{O} \rightarrow \mathrm{KFe}_{3}\left(\mathrm{SO}_{4}\right)_{2}(\mathrm{OH})_{6}+\mathrm{H}^{+}+\mathrm{SO}_{4}{ }^{2-} \text { and } \\
\mathrm{FeS}_{2}(\mathrm{As})+\mathrm{O}_{2}+\mathrm{H}_{2} \mathrm{O} \rightarrow \mathrm{SO}_{4}{ }^{2-}+\mathrm{H}^{+}+\mathrm{Fe}(\mathrm{OH})_{3}+\mathrm{As}
\end{gathered}
$$

However, the saturation index calculations of jarosite are under saturated in most samples (Table 2). Except for one sample (KA V18) was found to saturate slightly (SI = 0.26) and difficult to detect in solid phase analysis. Additionally, the chemical data indicate that As is not released by pyrite oxidation due to the formation of FeAsS and $\mathrm{FeS}_{2}$ in the core samples (Fig. 3). Wang et al. (Wang et al., submitted) reported the newly uncovered As species as a carbon nanotube-associated arsenic (As species $\mathrm{P}-\mathrm{Ca}-\mathrm{Mg})$ in Mekong Delta sediments. Co-precipitation of $\mathrm{As}(\mathrm{V})$ with $\mathrm{Ca}$ and $\mathrm{Mg}$ potentially release As into aquifers In the reducing condition accompanying with cations such as $\mathrm{Ca}^{2+}$ and $\mathrm{Mg}^{2+}$. Moreover, $\mathrm{As}(\mathrm{V})$ fraction was also interpreted as As adsorbed onto $\mathrm{Fe} / \mathrm{Mn}$ (oxyhydr)oxides. The correlation strongly suggests that the As in groundwater beneath the Khanh An commune is derived from reductive dissolution $\mathrm{Fe} / \mathrm{Mn}$ (oxyhydr)oxides and displacement of $\mathrm{As}$ by $\mathrm{HCO}_{3}^{-}$from and clay minerals in sediments.

\subsection{Relationship between Electrical Conductivity and As Concentrations}

Our study site is located in the region where groundwater salinity is below $1 \mathrm{~g} / \mathrm{L}$ TDS (Buschmann et al., 2008). In soils with low salt content, $\mathrm{EC}_{\mathrm{a}}$ is strongly influenced by variations in clay and moisture contents, which depend on changes in soil type and hydrology (Doolittle et al., 2014). Higher $\mathrm{EC}_{\mathrm{a}}$ values are attributed to the presence of higher clay content in upper $(5 \mathrm{~m})$ soil and wetter soil conditions (Aziz et al., 2008; Doolittle et al., 2014; Mcneill, 1990), but it is difficult to distinguish the respective contribution of these two factors to the high observed conductivity. However, previous studies have shown that the controlling factor in some areas is clay content, which is presented in Table 3 (Aziz et al., 2008; Hedley et al., 2004; Weller et al., 2007). In addition, As is also strongly adsorbed to clay particles which are transported through the river system as suspended load during the flooding stage (Nguyen \& Itoi, 2009). The electrical conductivity can identify the relative distribution of fine- and coarse-grained or permeable and impermeable surface layer, which has an important control on the spatial pattern of As in groundwater. In a study performed in Bangladesh, electrical conductivity was shown to be higher than $35 \mathrm{mS} / \mathrm{m}$ in areas where the clay content of the soil was higher than $60 \%$ (Aziz et al., 2008). A comparison between maps interpolating EM conductivity and the distribution of As in 
shallow wells is shown in Fig. 2. All wells in the area are contaminated by As, with an average concentration of $590 \mathrm{ppb}(\mathrm{n}=40$ samples). Concentrations of As in shallow aquifers tend to be lower underlying sandy soils (EM conductivity $<10 \mathrm{mS} / \mathrm{m}$ ) and higher below finer-grained and high conductivity soils as shown by Métral et al. (2008) and Aziz et al. (2008) (Aziz et al., 2008; Métral et al., 2008). Low-As aquifers are located underneath the areas with relatively sandy surface materials and far from the River. Clay pan and finer materials act as a "cap" which prevents oxygen to enter the shallow aquifer from atmosphere, rainwater or river water and thus to enhance reducing conditions and thus increase as concentration

Table 3. Correlations between electrical ground conductivity $(\sigma)$ and clay content

\begin{tabular}{ccccc}
\hline Place & Instrument & $\begin{array}{c}\text { Prediction of clay content } \\
(\mathbf{\%})\end{array}$ & $\mathbf{R}^{2}$ & Reference \\
\hline Klostergut Shceyern (Germany) & EM 38 & Clay $=-6.4+0.75 \sigma$ & 0.85 & Weller et al. (2007) \\
Araihazar (Bangladesh) & EM 31 & Clay $=-(3.97 \pm 1.5)+(0.91 \pm 0.1) \sigma$ & 0.85 & Aziz et al. (2008) \\
Manawatu (New Zealand) & EM 38 & Clay $=-22.496+1.682 \sigma$ & 0.72 & Hedley et al. (2004) \\
\hline
\end{tabular}

On the basis of this calculation, we compare $\mathrm{As}$ and $\mathrm{HCO}_{3}{ }^{-}$contents of each shallow well with the closest electrical conductivity value. Linear regression shows a slight correlation for 27-paired measurements corresponding to an increase in As concentrations $\left(R^{2}=0.34\right)$ and alkalinity $\left(R^{2}=0.33\right)$ as a function of electrical conductivity $(\sigma)$. Arsenic contamination in the Mekong Delta trends strongly to depend on oxygenated input from high-stand river which relates to the depth and age of the aquifer and the average value also decreases with distance from River (Buschmann et al., 2008; Luu et al., 2009; Merola et al., 2015; Nguyen \& Itoi, 2009). For a more quantitative comparison between groundwater and conductivity data, we return to the actual EM data by comparing the As content of each shallow well in the natural soil. To determine the relevant spatial scales, the depth of well and distance to the river, we estimate the minimum distance over which recharged water has to travel to the well (Fig. 5a). The correlation between electrical conductivity, the $\mathrm{HCO}_{3}^{-} / \mathrm{D}$ and $\mathrm{As} / \mathrm{D}$ ratios are highly significant with $\mathrm{R}^{2}=0.83$ and 0.78 respectively (Fig. 5b-c). These results confirm previous studies where high As concentrations in groundwater were correlated with high $\mathrm{HCO}_{3}^{-}$concentrations (Charlet et al., 2007; Nickson et al., 2000). The displacing effect of $\mathrm{HCO}_{3}^{-}$on $\mathrm{As}$ sorbed on $\mathrm{Fe} / \mathrm{Mn}$ (oxyhydr)oxides and the rate of increasing As concentrations with the depth in shallow aquifers might depend on the clay content of surface soil inferred from electrical conductivity. The observed trends in groundwater arsenic in Khanh An are consistent with known natural processes that promote contamination similar to most areas are located near Mekong Delta River and Bassac River (Erban et al., 2013; Kocar \& Fendorf, 2012; Ying, Damashek, Fendorf et al., 2015).

\section{Conclusion}

High levels of As in tube wells are causing the greatest risk to human health in An Giang province. The solid phase As speciation suggests that As is not only in iron (oxyhydr)oxides, but also is present as Sbound $\mathrm{As}(\mathrm{III})$ in the sediments. Upon reductive dissolution of iron (oxyhydr)oxides, As, Fe and high alkalinity are released in the anoxic aquifer. Electromagnetic (EM 31) investigations of shallow subsurface within a small area located in the Mekong Delta Vietnam indicated that variations in As concentration within the shallow Holocene aquifers seem to be controlled by the heterogeneity in near surface sediment and recharge of aquifers. The present geophysical data reveal a significant relationship between electrical conductivity, As and $\mathrm{HCO}_{3}^{-}$concentration in shallow aquifers of Khanh An. As concentrations in function of transport average distance affected by oxygenated water input from highstand river tend to increase together with high electrical conductivity of soils. Survey of electrical conductivity and As concentration should be extended to areas of lower As concentrations and variations in hydraulic head measurement be reported monthly to estimate the recharge from horizontal and vertical permeability (Aziz et al., 2008). The challenge would also be to extend the area of the EM survey to achieve a better understanding of the correlation between as concentrations and EM measurements. The future objectives should be therefore to consider the permeability of surface soils, 
the distribution of groundwater ages, the vertical recharge due to precipitation, monsoonal flooding and irrigation waters and the horizontal recharge from the River. However, the present study shows that easy and cheap electrical conductivity measurements can be used to differentiate areas where this recharge may occur (low EC) from areas where it does not (high EC, high clay soil content) and where high As is favored in the underlying "sealed" aquifer.
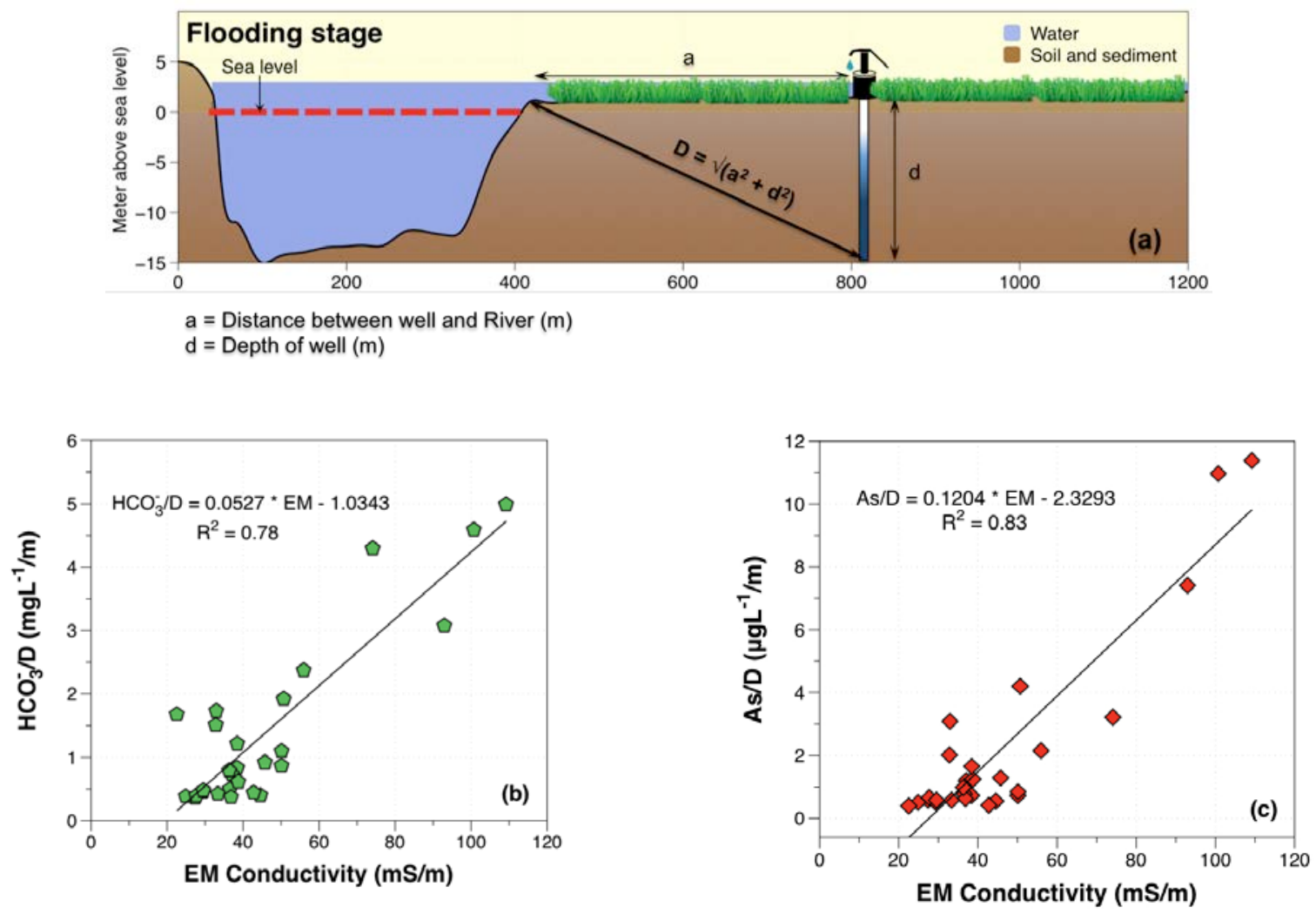

Figure 5. (a) Calculation of the minimum distance recharged water has to travel to the well (D). Comparison of (b) HCO3-/D and (c) As/D as a function of the closet electrical conductivity measurement.

Acknowledgments. The authors acknowledge the financial support of the doctoral scholarship from University Grenoble Alpes, France and Geochemistry group which is part of Labex OSUG@2020 (ANR10 LABX56). This study has been conducted under the framework of CARE-RESCIF initiative. We give special thanks to Y. Wang, M. P. Asta from EPFL, Le-Phu Vo and Quoc-Tuc Dinh from HCMUT for helping with collecting sediment and fieldwork in Vietnam. We also thank Francesco D'Acapito and Giovanni Lepore for the assistance during XAS measurements at the LISA beamline at the ESRF (BM08). We also thank the staff of Museo di Storia Naturale, Università di Firenze, especially L. Poggi, for kindly providing the arsenian pyrite reference.

\section{References}

1. Agusa, T., Kubota, R., Kunito, T., Tu, B. M., Pham, T. K. ., Chamnan, C., ... Tanabe, S. (2007). Arsenic Pollution in Groundwater of Vietnam and Cambodia: A Review. Biomed Res Trace Elements, 18(1), 35-47.

2. Agusa, T., Pham, T. K. T., Vi, M. L., Duong, H. A., Tanabe, S., Pham, H. V, \& Berg, M. (2014). Human exposure to arsenic from drinking water in Vietnam. Science of the Total Environment, 488-489, 562-569. http://doi.org/10.1016/j.scitotenv.2013.10.039

3. Andersen, C. B. (2002). Understanding Carbonate Equilibria By Measuring Alkalinity in Experimental and Natural Systems. Geoscience Education, 50(4), 389-403. 
4. Appelo, C. A. J., Van Der Weiden, M. J. J., Tournassat, C., \& Charlet, L. (2002). Surface complexation of ferrous iron and carbonate on ferrihydrite and the mobilization of arsenic. Environmental Science and Technology, 36(14), 3096-3103. http://doi.org/10.1021/es010130n

5. Asta, M. P., Cama, J., Martínez, M., \& Giménez, J. (2009). Arsenic removal by goethite and jarosite in acidic conditions and its environmental implications. Journal of Hazardous Materials, 171(1-3), 965-972. http://doi.org/10.1016/j.jhazmat.2009.06.097

6. Aziz, Z., Geen, A. Van, Stute, M., Versteeg, R., Horneman, A., Zheng, Y., ... Ahmed, K. M. (2008). Impact of local recharge on arsenic concentrations in shallow aquifers inferred from the electromagnetic conductivity of soils in Araihazar, Bangladesh. Water Resources Research, 44, 1-15. http://doi.org/10.1029/2007WR006000

7. Bardelli, F., Cattaruzza, E., Gonella, F., Rampazzo, G., \& Valotto, G. (2011). Characterization of road dust collected in Traforo del San Bernardo highway tunnel: Fe and Mn speciation. Atmospheric Environment, 45(35), 6459-6468. http://doi.org/10.1016/j.atmosenv.2011.07.035

8. Berg, M., Stengel, C., Pham, T. K. T., Pham, H. V, Sampson, M. L., Leng, M., ... Fredericks, D. (2007). Magnitude of arsenic pollution in the Mekong and Red River Deltas - Cambodia and Vietnam. Science of the Total Environment, 372, 413-425. http://doi.org/10.1016/j.scitotenv.2006.09.010

9. Buschmann, J., Berg, M., Stengel, C., Winkel, L., Sampson, M. L., Trang, P. T. K., \& Viet, P. H. (2008). Contamination of drinking water resources in the Mekong delta floodplains: Arsenic and other trace metals pose serious health risks to population. Environment International, 34(6), 756-764. http://doi.org/10.1016/j.envint.2007.12.025

10. Chakraborty, S., Bardelli, F., \& Charlet, L. (2010). Reactivities of Fe(II) on Calcite: Selenium Reduction. Environmental Science \& Technology, 44(4), 1288-1294.

11. Charlet, L., Chakraborty, S., Appelo, C. A. J., \& Roman-ross, G. (2007). Chemodynamics of an arsenic "hotspot"" in a West Bengal aquifer: A field and reactive transport modeling study. Applied Geochemistry, 22, 1273-1292. http://doi.org/10.1016/j.apgeochem.2006.12.022

12. Charlet, L., Morin, G., Rose, J., Wang, Y., Auffan, M., Burnol, A., \& Fernandez-Martinez, A. (2011). Reactivity at (nano)particle-water interfaces, redox processes, and arsenic transport in the environment. Comptes Rendus Geoscience, 343, 123-139. http://doi.org/10.1016/j.crte.2010.11.005

13. Doolittle, J. A., Brevik, E. C., Doolittle, J. A., \& Brevik, E. C. (2014). The use of electromagnetic induction techniques in soils studies. Geoderma, (223-225), 33-45.

14. Doolittle, J. A., Sudduth, K. A., Kitchen, N. R., \& Indorante, S. J. (1994). Estimating depths to claypans using electromagnetic induction methods. Soil and Water Conservation, 49(6), 572-575

15. Erban, L. E., Gorelick, S. M., \& Fendorf, S. (2014). Arsenic in the Multi-aquifer System of the Mekong Delta, Vietnam: Analysis of Large-Scale Spatial Trends and Controlling Factors. Environmental Science \& Technology, 48(11), 6081-6088. http://doi.org/10.1021/es403932t

16. Erban, L. E., Gorelick, S. M., Zebker, H. a, \& Fendorf, S. (2013). Release of arsenic to deep groundwater in the Mekong Delta, Vietnam, linked to pumping-induced land subsidence. Proceedings of the National Academy of Sciences of the United States of America, 110(34), 13751-6. http://doi.org/10.1073/pnas.1300503110

17. Farquhar, M. L., Charnock, J. M., Livens, F. R., \& Vaughan, D. J. (2002). Mechanisms of Arsenic Uptake from aqueous solution by interaction with Goethite, Lepidocrocite, Mackinawite, and Pyrite: An X-ray Absorption Spectroscopy Study. Environmental Science and Technology, 26, 1757-1762.

18. Fernández-Martínez, A., Román-Ross, G., Cuello, G. J., Turrillas, X., Charlet, L., Johnson, M. R., \& Bardelli, F. (2006). Arsenic uptake by gypsum and calcite: Modelling and probing by neutron and X-ray scattering. Physica B: Condensed Matter, 385-386, 935-937. http://doi.org/10.1016/j.physb.2006.05.276

19. Ghosal, U., Sikdar, P. K., \& Mcarthur, J. M. (2014). Palaeosol Control of Arsenic Pollution: The Bengal Basin in West Bengal, India. Groundwater, 53(4), 588-599. http://doi.org/10.1111/gwat.12251

20. Guo, H., Li, Y., Zhao, K., Ren, Y., \& Wei, C. (2011). Removal of arsenite from water by synthetic siderite: behaviors and mechanisms. Journal of Hazardous Materials, 186, 1847-54.

http://doi.org/10.1016/j.jhazmat.2010.12.078

21. Guo, H., Stüben, D., \& Berner, Z. (2007a). Adsorption of arsenic(III) and arsenic(V) from groundwater using natural siderite as the adsorbent. Journal of Colloid and Interface Science, 315(1), 47-53.

http://doi.org/10.1016/j.jcis.2007.06.035 
22. Guo, H., Stüben, D., \& Berner, Z. (2007b). Arsenic removal from water using natural iron mineral-quartz sand columns. The Science of the Total Environment, 377, 142-51. http://doi.org/10.1016/j.scitotenv.2007.02.001

23. Hanh, H. T., Kim, K. W., Bang, S., \& Hoa, N. M. (2011). Community exposure to arsenic in the Mekong river delta, Southern Vietnam. Journal of Environmental Monitoring, 13(7), 2025-32. http://doi.org/10.1039/c1em10037h

24. Hedley, C. B., Yule, I. J., Eastwood, C. R., Shepherd, T. G., \& Arnold, G. (2004). Rapid identification of soil textural and management zones using electromagnetic induction sensing of soils. Australian Journal of Soil Research, 42(4), 389-400. http://doi.org/10.1071/SR03149

25. Helz, G. R., \& Tossell, J. A. (2008). Thermodynamic model for arsenic speciation in sulfidic waters: A novel use of ab initio computations. Geochimica et Cosmochimica Acta, 72, 4457-4468.

http://doi.org/10.1016/j.gca.2008.06.018

26. Hoang, T. H., Bang, S., Kim, K.-W., Nguyen, M. H., \& Dang, D. M. (2010). Arsenic in groundwater and sediment in the Mekong River delta, Vietnam. Environmental Pollution, 158, 2648-58.

http://doi.org/10.1016/j.envpol.2010.05.001

27. Isaure, M.-P., Laboudigue, A., Manceau, A., Sarret, G., Tiffreau, C., Trocellier, P., ... Chateigner, D. (2002). Quantitative Zn speciation in a contaminated dredged sediment by $\mu$-PIXE, $\mu$-SXRF, EXAFS spectroscopy and principal component analysis. Geochimica et Cosmochimica Acta, 66(9), 1549-1567. http://doi.org/10.1016/S0016-7037(01)00875-4

28. Kelly, W. R., Holm, T. R., Wilson, S. D., \& Roadcap, G. S. (2005). Arsenic in Glacial Aquifers: Sources and Geochemical Controls. Groundwater, 43(4), 500-510.

29. Kocar, B. D., \& Fendorf, S. (2012). Arsenic Release and Transport in Sediments of the Mekong Delta. Environmental Pollution and Ecotoxicology, 117-124.

30. Kumar, P., Avtar, R., Kumar, A., Singh, C. K., Tripathi, P., Senthil, K. G., \& Ramanathan, A. L. (2014). Geophysical approach to delineate arsenic hot spots in the alluvial aquifers of Bhagalpur district, Bihar (India) in the central Gangetic plains. Applied Water Science, 4, 89-97. http://doi.org/10.1007/s13201-013-0133-y

31. Langner, P., Mikutta, C., \& Kretzschmar, R. (2011). Arsenic sequestration by organic sulphur in peat. Nature Geoscience, 5(1), 66-73. http://doi.org/10.1038/ngeo1329

32. Luu, T. T. G., Sthiannopkao, S., \& Kim, K. W. (2009). Arsenic and other trace elements contamination in groundwater and a risk assessment study for the residents in the Kandal Province of Cambodia. Environment International, 35(3), 455-460. http://doi.org/10.1016/j.envint.2008.07.013

33. Mandal, B. K., \& Suzuki, K. T. (2002). Arsenic round the world: a review. Talanta, 58, 201-35.

34. McArthur, J. M., Banerjee, D. M., Hudson-Edwards, K. A., Mishra, R., Purohit, R., Ravenscroft, P., ... Chadha, D. K. (2004). Natural organic matter in sedimentary basins and its relation to arsenic in anoxic ground water: the example of West Bengal and its worldwide implications. Applied Geochemistry, 19, 1255-1293. http://doi.org/10.1016/j.apgeochem.2004.02.001

35. Mcneill, J. D. (1990). Use of Electromagnetic Methods for Groundwater Studies. Geotechnical and Environmental Geophysics (Ward SN). Society of Exploration Geophysicists, Tulsa, UK.

36. Merola, R. B., Hien, T. T., Quyen, D. T. T., \& Vengosh, A. (2015). Arsenic exposure to drinking water in the Mekong Delta. Science of the Total Environment, 511, 544-552. http://doi.org/10.1016/j.scitotenv.2014.12.091

37. Métral, J., Charlet, L., Bureau, S., Mallik, S. B., Chakraborty, S., Ahmed, K. M., ... van Geen, A. (2008). Comparison of dissolved and particulate arsenic distributions in shallow aquifers of Chakdaha, India, and Araihazar, Bangladesh. Geochemical Transactions, 9. http://doi.org/10.1186/1467-4866-9-1

38. Moore, D. M., \& Reynolds, R. C. (1997). X-Ray diffraction and the identification and analysis of clay minerals,. Oxford University Press, Oxford, New York (2nd Ed.).

39. Nath, B., Mallik, S. B., Stüben, D., Chatterjee, D., \& Charlet, L. (2010). Electrical resistivity investigation of the arsenic affected alluvial aquifers in West Bengal, India: Usefulness in identifying the areas of low and high groundwater arsenic. Environmental Earth Sciences, 60(4), 873-884. http://doi.org/10.1007/s12665-009-0224-0

40. Ng, J. C., Wang, J., \& Shraim, A. (2003). A global health problem caused by arsenic from natural sources. Chemosphere, 52(9), 1353-9. http://doi.org/10.1016/S0045-6535(03)00470-3

41. Nguyen, K. P., \& Itoi, R. (2009). Source and release mechanism of arsenic in aquifers of the Mekong Delta, Vietnam. Journal of Contaminant Hydrology, 103, 58-69. http://doi.org/10.1016/j.jconhyd.2008.09.005 
42. Nickson, R. T., Mcarthur, J. M., Ravenscroft, P., Burgess, W. G., \& Ahmed, K. M. (2000). Mechanism of arsenic release to groundwater, Bangladesh and West Bengal. Applied Geochemistry, 15(4), 403-413. http://doi.org/10.1016/S0883-2927(99)00086-4

43. Pal, A., Saha, S., Maji, S. K., Kundu, M., \& Kundu, A. (2012). Wet-chemical synthesis of spherical arsenic nanoparticles by a simple reduction method and its characterization. Advanced Materials Letters, 3(3), 177-180. http://doi.org/10.5185/amlett.2011.9305

44. Parkhurst, B. D. L., \& Appelo, C. A. J. (1999). User's guide to PhreeqC (Version 2) - A computer program for speciation, batch-reaction, one-dimensional transport, and inverse geochemical calculations. U.S. Department of the Interior, U.S. Geological Survey.

45. Pellerin, L. (2002). Applications of electrical and electromagnetic methods for environmental and geotechnical investigations. Surveys in Geophysics, 23, 101-132. http://doi.org/10.1023/A:1015044200567

46. Pettersson, J. K., \& Nobes, D. C. (2003). Environmental geophysics at Scott Base: Ground penetrating radar and electromagnetic induction as tools for mapping contaminated ground at Antarctic research bases. Cold Regions Science and Technology, 37(2), 187-195. http://doi.org/10.1016/S0165-232X(03)00037-5

47. Polizzotto, M. L., Harvey, C. F., Sutton, S. R., \& Fendorf, S. (2005). Processes conducive to the release and transport of arsenic into aquifers of Bangladesh. Proceedings of the National Academy of Sciences, 102(52), 18819-18823.

48. Postma, D., Larsen, F., Minh Hue, N. T., Duc, M. T., Viet, P. H., Nhan, P. Q., \& Jessen, S. (2007). Arsenic in groundwater of the Red River floodplain, Vietnam: Controlling geochemical processes and reactive transport modeling. Geochimica et Cosmochimica Acta, 71(21), 5054-5071. http://doi.org/10.1016/j.gca.2007.08.020

49. Raab, A., Meharg, A. A., Jaspars, M., \& Genney, R. (2004). Arsenic-glutathione complexes - their stability in solution and during separation by different HPLC modes. Journal of Analytical Atomic Spectrometry, 19, 183190.

50. Ravel, B., \& Newville, M. (2005). Athena, Artemis, Hephaestus: Data analysis for X-ray absorption spectroscopy using Ifeffit. Journal of Synchrotron Radiation, 12(4), 537-541. http://doi.org/10.1107/S0909049505012719

51. Román-Ross, G., Cuello, G. J., Turrillas, X., Fernández-Martínez, A., \& Charlet, L. (2006). Arsenite sorption and co-precipitation with calcite. Chemical Geology, 233, 328-336. http://doi.org/10.1016/j.chemgeo.2006.04.007

52. Smedley, P. L., \& Kinniburgh, D. G. (2002). A review of the source, behaviour and distribution of arsenic in natural waters. Applied Geochemistry, 17(5), 517-568. http://doi.org/10.1016/S0883-2927(02)00018-5

53. Smith, A. H., Ercumen, A., Yuan, Y., \& Steinmaus, C. M. (2009). Increased lung cancer risks are similar whether arsenic is ingested or inhaled. J Expo Sci Environ Epidemiol, 19(4), 343-348. http://doi.org/10.1038/jes.2008.73

54. Smith, A. H., Hopenhayn-Rich, C., Bates, M. N., Goeden, H. M., Hertz-Picciotto, I., Duggan, H. M., ... Smith, M. T. (1992). Cancer risks from arsenic in drinking water. Environmental Health Perspectives, 97(6), 259-267. http://doi.org/10.1289/ehp.9297259

55. SØ, H. U., Postma, D., Jakobsen, R., \& Larsen, F. (2008). Sorption and desorption of arsenate and arsenite on calcite. Geochimica et Cosmochimica Acta, 72(24), 5871-5884. http://doi.org/10.1016/j.gca.2008.09.023

56. Stanger, G., Truong, T. Van, Ngoc, K. S. L. T. M., Luyen, T. V, \& Thanh, T. T. (2005). Arsenic in groundwaters of the Lower Mekong. Environmental Geochemistry and Health, 27(4), 341-57. http://doi.org/10.1007/s10653-005-3991-x

57. Stuckey, J. W., Schaefer, M. V, Benner, S. G., \& Fendorf, S. (2015). Reactivity and speciation of mineralassociated arsenic in seasonal and permanent wetlands of the Mekong Delta. Geochimica et Cosmochimica Acta, 171, 143-155. http://doi.org/10.1016/j.gca.2015.09.002

58. Stuckey, J. W., Schaefer, M. V, Kocar, B. D., Benner, S. G., \& Fendorf, S. (2015). Arsenic release metabolically limited to permanently water-saturated soil in Mekong Delta. Nature Geoscience, 8, 1-9. http://doi.org/10.1038/NGEO2589

59. Suess, E., Wasserforschungs-institut, E. Das, Planer-friedrich, B., Suess, E., \& Planer-friedrich, B. (2012). Thioarsenate formation upon dissolution of orpiment and arsenopyrite Thioarsenate formation upon dissolution of orpiment and arsenopyrite. Chemosphere, 89(July 2015), 1390-1398.

http://doi.org/10.1016/j.chemosphere.2012.05.109 
60. Wang, Y., Pape, P. Le, Morin, G., Suvorova, E., Bártová, B., Asta, M. P., ... Bernier-Latmani, R. (n.d.). A carbon nanotube-associated arsenic phosphate in Mekong Delta sediments. Nature Geonature.

61. Weller, U., Zipprich, M., Sommer, M., Castell, W. Z., \& Wehrhan, M. (2007). Mapping Clay Content across Boundaries at the Landscape Scale with Electromagnetic Induction. Soil Science Society of America Journal, 71(6), 1740. http://doi.org/10.2136/sssaj2006.0177

62. WHO. (2004). Some Drinking-water disinfectants and Contaminants, including Arsenic (Vol. 83).

63. Winkel, L. H. E., Trang, P., Vi, L., Stengel, C., Amini, M., Nguyen, H., ... Berg, M. (2010). Arsenic pollution of groundwater in Vietnam exacerbated by deep aquifer exploitation for more than a century. PNAS, 108(4), 12461251.

http://doi.org/10.1073/pnas.1011915108/-/DCSupplemental.www.pnas.org/cgi/doi/10.1073/pnas.1011915108

64. Wolthers, M., Charlet, L., van Der Weijden, C. H., van der Linde, P. R., \& Rickard, D. (2005). Arsenic mobility in the ambient sulfidic environment: Sorption of $\operatorname{arsenic}(\mathrm{V})$ and $\operatorname{arsenic}(\mathrm{III})$ onto disordered mackinawite. Geochimica et Cosmochimica Acta, 69(14), 3483-3492. http://doi.org/10.1016/j.gca.2005.03.003

65. Ying, S. C., Damashek, J., Fendorf, S., \& Francis, C. A. (2015). Indigenous arsenic (V) -reducing microbial communities in redox-fluctuating near-surface sediments of the Mekong Delta. Geobiology. http://doi.org/10.1111/gbi.12152 